\title{
A MULTIPOINT INITIAL-FINAL VALUE PROBLEM FOR A LINEAR MODEL OF PLANE-PARALLEL THERMAL CONVECTION IN VISCOELASTIC INCOMPRESSIBLE FLUID
}

\author{
S.A. Zagrebina, South Ural State University, Chelyabinsk, Russian Federation, \\ zagrebina_sophiya@mail.ru
}

The linear model of plane-parallel thermal convection in a viscoelastic incompressible Kelvin-Voigt material amounts to a hybrid of the Oskolkov equations and the heat equations in the Oberbeck-Boussinesq approximation on a two-dimensional region with Bénard's conditions. We study the solvability of this model with the so-called multipoint initialfinal conditions. We use these conditions to reconstruct the parameters of the processes in question from the results of multiple observations at various points and times. This enables us, for instance, to predict emergency situations, including the violation of continuity of thermal convection processes as a result of breaching technology, and so forth.

For thermal convection models, the solvability of Cauchy problems and initial-final value problems has been studied previously. In addition, the stability of solutions to the Cauchy problem has been discussed. We study a multipoint initial-final value problem for this model for the first time. In addition, in this article we prove a generalized decomposition theorem in the case of a relatively sectorial operator. The main result is a theorem on the unique solvability of the multipoint initial-final value problem for the linear model of planeparallel thermal convection in a viscoelastic incompressible fluid.

Keywords: multipoint initial-final value problem; Sobolev-type equation; generalized splitting theorem; linear model of plane-parallel thermal convection in viscoelastic incompressible fluid.

Many phenomena and processes in economics, physics, and technology, like, for instance, plane-parallel thermal convection in viscoelastic incompressible fluid, are modelled by linear

$$
L \dot{u}=M u+f
$$

and nonlinear

$$
L \dot{u}=M u+N(u)+f
$$

Sobolev-type equations [33]. The interest in Sobolev-type equations, which nowadays form a large subfield of nonclassical equations of mathematical physics [30], has been increasing recently; see the wonderful historical survey in [31].

The goal of our study is the solvability of (1) with the so-called multipoint initial-final conditions (see [5] for instance and reference therein)

$$
\begin{gathered}
P_{j}\left(u\left(\tau_{j}\right)-u_{j}\right)=0, \quad u_{j} \in \mathfrak{U}, \quad j=\overline{0, n} \\
-\infty \leq a<\tau_{0}<\tau_{1}<\ldots<\tau_{j}<\tau_{j+1}<\ldots<b \leq+\infty,
\end{gathered}
$$

where $P_{j}$ are relative spectral projectors (we discuss them in Section 4 ), while $u_{j}$ are arbitrary vectors in a Banach space $\mathfrak{U}$. These conditions are used to reconstruct the parameters of the 
processes in question from the results of multiple observations at various points and times. This enables us to, for instance, predict emergency situations, including the violation of continuity of thermal convection processes as a result of breaching technology, and so forth.

We should note that problem (1), (3) in the case $n=1$ (the initial-final value problem) has been studied quite actively in various aspects. In particular, there are results concerning the optimal control of the solution to these problems [9], including Sobolev-type equations of high order [6].

The history of problem (1), (3) in the case $n=1$ starts on the one hand in [12], where it is called Verigin's problem, and on the other hand, independently, in [32], where it is called the conjugation problem. However, in both cases instead of relatively spectral projectors $P_{0}$ and $P_{1}$ we consider spectral projectors of the operator $L$ on assuming it to be selfadjoint. The first results in this direction are presented in [19], which treats a particular case of problem (1), (3) with, moreover, more rigid conditions on the $L$-spectrum of $M$ than here. Problem (1), (3) is considered in [2] with the same conditions on the $L$-spectrum of $M$ as in [19]; however, in this case the possibility of greater freedom in relatively spectral conditions is mentioned. We should note that there were attempts to study [18] the solvability of a particular case of problem (2) for nonlinear Sobolev-type equations (3) in the case $n=1$, but as yet these studies have not been pushed further. In addition, if in (3) we put $n=0$ then problem (3) reduces to the ShowalterSidorov problem [20], which has already played an important role in a number of models with applications to economics [7] and technology [29].

Our approach rests on the theory of relatively $p$-sectorial operators and degenerate analytic resolving semigroups of operators. Sviridyuk [14] pioneered the concept of a relatively sectorial operator. He showed that relative sectoriality of an operator naturally generalizes the concept of sectoriality [28]. However, it soon turned out that relative sectoriality generalizes the concept of relative $\sigma$-boundedness of an operator only in the case that the $L$-resolvent of $M$ has a removable singularity at infinity. In order to fill this embarrassing gap, Bokareva introduced [16] the concept of relative $p$-sectoriality of an operator, generalizing the concept of relative $\sigma$-boundedness in the case that the $L$-resolvent of $M$ has a pole at infinity. Then, relatively strongly $p$-sectorial operators on the right (on the left) [16] and relatively strongly $p$-sectorial operators [24], [25] were introduced. Subsequently, relatively $p$-sectorial operators were studied in various situations. Namely, Dudko studied [1] the case that both operators are closed and the spaces $\mathfrak{U}$ and $\mathfrak{F}$ coincide; Efremov studied [17] optimal control problems for Sobolev-type equations with relatively $p$ sectorial operators; Keller found [21] sufficient, and in some cases necessary, conditions for the existence of bounded solutions to these equations; Kuznetsov [22] began to search for relatively $p$ sectorial operators among elliptic operators; Yakupov used [26] relatively $p$-sectorial operators to study the phase spaces of certain problems in the hydrodynamics of viscoelastic fluid.

Consider now a precursor of (2): a hybrid of Oskolkov's system [11] and the heat equation in the Oberbeck-Boussinesq approximation [8],

$$
\left\{\begin{array}{c}
\left(\lambda-\nabla^{2}\right) v_{t}=\nu \nabla^{2} v-(v \cdot \nabla) v-\nabla p+g \gamma S, \nabla \cdot v=0 \\
S_{t}=\delta \nabla S-v \cdot \nabla S+\gamma \cdot v
\end{array}\right.
$$

modeling thermal convection in a viscoelastic incompressible Kelvin-Voigt material [23]. Here $v=\left(v_{1}, v_{2}, \cdots, v_{n}\right)$ with $v_{i}=v_{i}(x, t)$ and $n=2$ or 3 is the vector function representing fluid velocity; the scalar functions $S=S(x, t)$ and $p=p(x, t)$ represent the temperature and pressure of the fluid; the parameters $\lambda \in \mathbb{R}, \nu \in \mathbb{R}_{+}$, and $\delta \in \mathbb{R}_{+}$characterize the elasticity, viscosity, and thermal conductivity of the fluid; $g \in \mathbb{R}_{+}$is the free fall acceleration; finally, $\gamma=(0, \ldots, 0,1) \in \mathbb{R}^{n}$ and $x=\left(x_{1}, x_{2}, \cdots, x_{n}\right)$. When one of the horizontal components of the velocity vanishes, (4) 
becomes

$$
\left\{\begin{array}{c}
(\lambda-\Delta) \Delta \frac{\partial \psi}{\partial t}=\nu \Delta^{2} \psi-\frac{\partial(\psi, \Delta \psi)}{\partial(x, y)}+\alpha \frac{\partial \theta}{\partial x}, \\
\frac{\partial \theta}{\partial t}=\delta \Delta \theta-\frac{\partial(\psi, \theta)}{\partial(x, y)}+\beta \frac{\partial \psi}{\partial x},
\end{array}\right.
$$

which models plane-parallel thermal convection in a layer of viscoelastic incompressible KelvinVoigt material.

For (4) Sviridyuk considered the first initial-boundary value problem [13] and showed that it is solvable for arbitrary values of $\lambda$. Then jointly with Yakupov [26] he described the morphology of the phase space of the Cauchy-Bénard problem for (5). Sukacheva and Matveeva studied [27] the non-autonomous case of this problem. Subsequently they considered a generalized model of thermal convection [10], established the local solvability of the Cauchy problem for it, and found the solution numerically using the modified Galerkin method. We should also mention the studies [4] of the stability of solutions to the Cauchy-Bénard problem for (5) in a neighborhood of the origin. The existence of stable and unstable invariant manifolds in the problem was established basing on the Hadamard-Perron theorem. Note also that [3] showed the unique solvability of the initial-final value problem for the linearized model of thermal convection (4).

This article is devoted to a qualitative study of the multipoint initial-final value problem

$$
(\lambda-\Delta) \Delta \psi_{t}=-\nu \Delta^{2} \psi-\alpha \theta_{x}+\xi, \quad \theta_{t}=\delta \Delta \theta-\beta \psi_{x}+\zeta
$$

for the linear mathematical model of plane-parallel thermal convection in viscoelastic incompressible fluid in the region $\Omega=(0, a) \times(0, b) \in \mathbb{R}^{2}$ with Bénard's boundary conditions

$$
\begin{gathered}
\psi(x, 0, t)=\Delta \psi(x, 0, t)=\psi(x, b, t)=\Delta \psi(x, b, t)=0, \\
\theta(x, 0, t)=\theta(x, b, t)=0,
\end{gathered}
$$

the functions $\psi$ and $\theta$ are periodic in $x$ with period $a$.

In the first three sections we collect auxiliary facts of Sviridyuk's theory [15] of relatively $p$ sectorial operators and degenerate resolving semigroups of operators, adapted to our situation. In Section 1 we introduce the concept of a relatively $p$-sectorial operator. In Section 2 we consider degenerate resolving semigroups of operators and the construction of units of semigroups of operators. In Section 3 we consider conditions for the existence of the inverse operator. In Section 4 we prove a generalized splitting theorem for the spaces and actions of operators. There we construct relatively spectral projectors, which in this case are units of the semigroups of operators, on assuming relative $p$-sectoriality. In Section 5 we study the multipoint initial-final value problem for Sobolev-type equations with a relatively $p$-sectorial operator $M$. The main result of this section is a theorem on the unique solvability of problem (1), (3). In Section 6 we apply these abstract results to the linear model of plane-parallel thermal convection in viscoelastic incompressible fluid. There we reduce the stated problem to the abstract equation (1). We verify the $(L, 0)$-sectoriality of $M$. The main result of this section is the theorem on the unique solvability of the multipoint initial-final value problem (3). We should note that the author already discussed [34] a generalized decomposition theorem in the case of strongly $(L, p)$-radial operator. We make all arguments in real Banach spaces, but, while addressing spectral questions, introduce their natural complexifications. All contours are oriented counterclockwise and bound the region lying to the left as they are traversed. 


\section{Relatively $p$-sectorial Operators}

On assuming that $\mathfrak{U}$ and $\mathfrak{F}$ are Banach spaces, consider a continuous linear operator $L \in$ $\mathcal{L}(\mathfrak{U} ; \mathfrak{F})$ and a closed linear operator $M \in \mathcal{C l}(\mathfrak{U} ; \mathfrak{F})$ whose domain is dense. Introduce the $L$ resolving set $\rho^{L}(M)=\left\{\mu \in \mathbb{C}:(\mu L-M)^{-1} \in \mathcal{L}(\mathfrak{F} ; \mathfrak{U})\right\}$ and the $L$-spectrum $\sigma^{L}(M)=\mathbb{C} \backslash \rho^{L}(M)$ of $M$. Provided that $\rho^{L}(M) \neq \emptyset$, we can introduce the right and left

$$
R_{(\mu, p)}^{L}(M)=\prod_{k=0}^{p} R_{\mu_{k}}^{L}(M) \quad \text { and } \quad L_{(\mu, p)}^{L}(M)=\prod_{k=1}^{p} L_{\mu_{k}}^{L}(M)
$$

$(L, p)$-resolutions of $M$. Here $R_{\mu}^{L}(M)=(\mu L-M)^{-1} L$ and $L_{\mu}^{L}(M)=L(\mu L-M)^{-1}$, while $\mu_{k} \in \rho^{L}(M)$ for $k=0, \ldots, p$.

Definition 1. [15] An operator $M$ is called $p$-sectorial relatively to an operator $L$ with $p \in\{0\} \cup \mathbb{N}$ (or briefly, $(L, p)$-sectorial) whenever there exist constants $K \in \mathbb{R}_{+}, a \in \mathbb{R}$, and $\Theta \in(\pi / 2, \pi)$ such that

$$
S_{a, \Theta}^{L}(M)=\{\mu \in \mathbb{C}:|\arg (\mu-a)|<\Theta, \mu \neq a\} \subset \rho^{L}(M)
$$

furthermore,

$$
\max \left\{\left\|R_{(\mu, p)}^{L}(M)\right\|_{\mathcal{L}(\mathfrak{U})},\left\|L_{(\mu, p)}^{L}(M)\right\|_{\mathcal{L}(\mathfrak{F})}\right\} \leq \frac{K}{\prod_{k=0}^{p}\left|\mu_{k}-a\right|}
$$

for arbitrary $\mu_{k} \in S_{a, \Theta}^{L}(M)$ for $k=0, \ldots, p$.

Remark 1. If $M$ is an $(L, p)$-sectorial operator and $b \geq a$ then the operator $\tilde{M}=M-b L$ is also $(L, p)$-sectorial. Furthermore, we can choose the constant $a$ in 1 to be 0 . Assume henceforth that $S_{0, \Theta}^{L}(M)=S_{\Theta}^{L}(M)$.

Remark 2. If the operator $L \in \mathcal{L}(\mathfrak{U} ; \mathfrak{F})$ has continuous inverse then the sectoriality of the operator $L^{-1} M \in \mathcal{C l}(\mathfrak{U})$ implies the $(L, p)$-sectoriality of $M \in \mathcal{C l}(\mathfrak{U} ; \mathfrak{F})$, and the $(L, 0)$-sectoriality of $M$ implies the sectoriality of $L^{-1} M$ (or equivalently, of $M L^{-1}$ ).

Lemma 1. If $M$ is an $(L, p)$-sectorial operator then there exist $R>0$ and $C>0$ such that $\left\|(\mu L-M)^{-1}\right\|_{\mathcal{L}(\mathfrak{F} ; \mathfrak{l})} \leq C|\mu|^{p}$ for all $\mu \in S_{\Theta}^{L}(M) \backslash\{\mu \in \mathbb{C}:|\mu| \leq R\}$.

Remark 3. (i) If $M$ is an $(L, p)$-bounded operator and $\infty$ is an order 0 pole of the $L$-resolvent of $M$ then $M$ is an $(L, 0)$-sectorial operator.

(ii) If $M$ is an $(L, p)$-bounded operator and $\infty$ is a pole of order at most $p \in \mathbb{N}$ of the $L$ resolvent of $M$ then $M$ is an $(L, p)$-sectorial operator.

Lemma 2. The following claims hold for every $(L, p)$-sectorial operator $M$ :

(i) the length of every chain of generalized $M$-eigenvectors of $L$ is bounded by $p$;

(ii) the set $\operatorname{ker} R_{(\mu, p)}^{L}(M)$ coincides with the $M$-root space of $L$;

(iii) $\operatorname{ker} R_{(\mu, p)}^{L}(M) \cap \operatorname{im} R_{(\mu, p)}^{L}(M)=\{0\}$ and $\operatorname{ker} L_{(\mu, p)}^{L}(M) \cap \operatorname{im} L_{(\mu, p)}^{L}(M)=\{0\}$;

(iv) the operator $M_{0}^{-1} \in \mathcal{L}\left(\mathfrak{F}^{0} ; \mathfrak{U}^{0}\right)$ exists.

On assuming that $M$ is an $(L, p)$-sectorial operator, recall the notation $H=M_{0}^{-1} L_{0}$ and $G=L_{0} M_{0}^{-1}$. Denote by $\mathfrak{U}^{1}$ the closure of the linear subspace $\operatorname{im} R_{(\mu, p)}^{L}(M)$. Denote by $\tilde{\mathfrak{U}}$ the closure of the linear subspace $\mathfrak{U}^{0}+\operatorname{im} R_{(\mu, p)}^{L}(M)$ in the norm of $\mathfrak{U}$. Denote by $\mathfrak{F}^{1}$ the closure of the linear subspace $\operatorname{im} L_{(\mu, p)}^{L}(M)$, and by $\tilde{\mathfrak{F}}$ the closure of the linear subspace $\mathfrak{F}^{0} \dot{+} \operatorname{im} L_{(\mu, p)}^{L}(M)$ in the norm of $\mathfrak{F}$. 
Lemma 3. The following claims hold for every $(L, p)$-sectorial operator $M$ :

(i) the operators $H$ and $G$ are nilpotent of degree at most $p$;

(ii) $\lim _{\mu \rightarrow+\infty}\left(\mu R_{\mu}^{L}(M)\right)^{p+1} u=u$ for every $u \in \mathfrak{U}^{1}$ and $\lim _{\mu \rightarrow+\infty}\left(\mu L_{\mu}^{L}(M)\right)^{p+1} f=f$ for every $f \in \mathfrak{F}^{1} ;$

(iii) $\tilde{\mathfrak{U}}=\mathfrak{U}^{0} \oplus \mathfrak{U}^{1}$ and $\tilde{\mathfrak{F}}=\mathfrak{F}^{0} \oplus \mathfrak{F}^{1}$.

Denote the projector onto $\mathfrak{U}^{1}$ parallel to $\mathfrak{U}^{0}$ by $\tilde{P}=s^{-} \lim _{\mu \rightarrow+\infty}\left(\mu R_{\mu}^{L}(M)\right)^{p+1}$ and the projector onto $\mathfrak{F}^{1}$ parallel to $\mathfrak{F}^{0}$ by $\tilde{Q}=s^{-} \lim _{\mu \rightarrow+\infty}\left(\mu L_{\mu}^{L}(M)\right)^{p+1}$.

\section{Degenerate Analytic Resolving Semigroups of Operators}

On assuming that $\mathfrak{U}$ and $\mathfrak{F}$ are Banach spaces, take an operator $L \in \mathcal{L}(\mathfrak{U} ; \mathfrak{F})$ and an operator $M \in \mathcal{C l}(\mathfrak{U} ; \mathfrak{F})$. The equation

$$
L \dot{u}=M u
$$

reduces to the equivalent pair of equations

$$
\begin{aligned}
& R_{\mu}^{L}(M) \dot{u}=(\mu L-M)^{-1} M u, \\
& L_{\mu}^{L}(M) \dot{f}=M(\mu L-M)^{-1} f .
\end{aligned}
$$

It is convenient to regard (13) and (14) as concrete interpretations of the abstract equations

$$
A \dot{v}=B v
$$

defined on a Banach space $\mathfrak{V}$ with $A, B \in \mathcal{L}(\mathfrak{V})$. Refer as a solution to (15) to a vector function $v(t) \in C^{\infty}\left(\mathbb{R}_{+} ; \mathfrak{V}\right)$ satisfying this equation for $t>0$ and continuous at 0 .

Definition 2. A mapping $V^{\bullet}: \mathbb{R}_{+} \rightarrow \mathcal{L}(\mathfrak{V})$ is called a semigroup of resolving operators (or simply a resolving semigroup) of (15) whenever

(i) $V^{s} V^{t}=V^{s+t}$ for all $s, t>0$;

(ii) for every $v_{0} \in \mathfrak{V}$ the function $v(t)=V^{t} v_{0}$ is a solution to this equation.

A semigroup $\left\{V^{t}: t>0\right\}$ is called analytic whenever it can be analytically continued to some sector $\Sigma \subset \mathbb{C}$ including the ray $\mathbb{R}_{+}$, that is, there exists an analytic mapping $\tilde{V}^{\bullet}: \Sigma \rightarrow \mathcal{L}(\mathfrak{V})$ enjoying properties (i) and (ii) of the previous definition (with $s, t \in \Sigma$ ), coinciding with $V^{\bullet}$ on the positive semi-axis. In addition, $\left\{V^{t}: t>0\right\}$ is called uniformly bounded whenever $\left\|V^{t}\right\|_{\mathcal{L}(\mathfrak{V})} \leq$ const for all $t \in \mathbb{R}_{+}$.

Theorem 1. For every $(L, p)$-sectorial operator $M$ there exists a resolving semigroup $\left\{U^{t}: t>0\right\}$ (or $\left.\left\{F^{t}: t>0\right\}\right)$ of (13) (respectively (14)) which is analytic in the sector

$$
\Sigma=\{\tau \in \mathbb{C}:|\arg \tau|<\Theta-\pi / 2 \text { with } \tau \neq 0\},
$$

where we take $\Theta$ from Definition 1, and uniformly bounded. Furthermore, this semigroup is defined by the integrals

$$
U^{t}=\frac{1}{2 \pi i} \int_{\Gamma} R_{\mu}^{L}(M) e^{\mu t} d \mu \quad\left(F^{t}=\frac{1}{2 \pi i} \int_{\Gamma} L_{\mu}^{L}(M) e^{\mu t} d \mu\right)
$$

of Dunford-Taylor type, where $t \in \mathbb{R}_{+}$, and the contour $\Gamma \subset S_{a, \Theta}^{L}(M)$ satisfies $|\arg \mu| \rightarrow \Theta$ as $\mu \rightarrow \infty$ and $\mu \in \Gamma$. 
Lemma 4. If $M$ is an (L,p)-sectorial operator then $\lim _{t \rightarrow 0+} U^{t} u=u$ for every $u \in \operatorname{im} R_{(\mu, p)}^{L}(M)$ and $\lim _{t \rightarrow 0+} F^{t} f=f$ for every $\left.f \in \operatorname{im} L_{(\mu, p)}^{L}(M)\right)$.

Lemma 5. If $\left\{V^{t}: t>0\right\}$ is an analytic semigroup then $\operatorname{ker} V^{t_{1}}=\operatorname{ker} V^{t_{2}}$ for all $t_{1}, t_{2}>0$.

Definition 3. The set $\operatorname{ker} V^{\bullet}=\operatorname{ker} V^{t}, t>0$ is called the kernel of the analytic semigroup $\left\{V^{t}: t>0\right\}$.

The preceding statement shows that the kernel is well-defined.

Consider the kernels of the semigroups $U^{\bullet}$ and $F^{\bullet}$ :

$$
\operatorname{ker} U^{\bullet}=\left\{\varphi \in \mathfrak{U}: U^{t} \varphi=0 \exists t \in \mathbb{R}_{+}\right\}, \quad \operatorname{ker} F^{\bullet}=\left\{\psi \in \mathfrak{F}: F^{t} \psi=0 \exists t \in \mathbb{R}\right\} .
$$

Put $\mathfrak{U}^{0}=\operatorname{ker} U^{\bullet}$ and $\mathfrak{F}^{0}=\operatorname{ker} F^{\bullet}$. Denote by $L_{0}$ the restriction of $L$ to $\mathfrak{U}^{0}$, and by $M_{0}$ the restriction of $M$ to $\mathfrak{U}^{0} \cap \operatorname{dom} M$.

As in the case of holomorphic groups, it is clear from the expressions (16) of the resolving semigroups of (13) and (14) that their elements have nontrivial kernels $\operatorname{ker} U^{t} \supset \operatorname{ker} R_{\mu}^{L}(M)$ and $\operatorname{ker} F^{t} \supset \operatorname{ker} L_{\mu}^{L}(M)$ for every $t>0$.

The kernel of an analytic semigroup is obviously a subspace. Denote by $\hat{L}_{0}\left(\hat{M}_{0}\right)$ the restriction of $L(M)$ to $\operatorname{ker} U^{\bullet}\left(\operatorname{ker} U^{\bullet} \cap \operatorname{dom} M\right)$.

Lemma 6. If $M$ is an $(L, p)$-sectorial operator then

$$
\hat{L}_{0} \in \mathcal{L}\left(\operatorname{ker} U^{\bullet} ; \operatorname{ker} F^{\bullet}\right), \quad \hat{M}_{0}: \operatorname{ker} U^{\bullet} \cap \operatorname{dom} M \rightarrow \operatorname{ker} F^{\bullet} .
$$

Denote by $\sigma_{0}^{\hat{L}}(\hat{M})$ the $\hat{L}_{0}$-spectrum of $\hat{M}_{0}$.

Lemma 7. If $M$ is an $(L, p)$-sectorial operator then $\sigma_{0}^{\hat{L}}(\hat{M})$ contains no finite points.

Corollary 1. If $M$ is an $(L, p)$-sectorial operator then the operator $\hat{M}_{0}^{-1} \in \mathcal{L}\left(\operatorname{ker} F^{\bullet} ; \operatorname{ker} U^{\bullet}\right)$ exists.

Theorem 2. If $M$ is an $(L, p)$-sectorial operator then $\operatorname{ker} U^{\bullet}=\mathfrak{U}^{0}$ and $\operatorname{ker} F^{\bullet}=\mathfrak{F}^{0}$.

Definition 4. Refer as the image of a semigroup $\left\{V^{t}: t>0\right\}$ to the set

$$
\operatorname{im} V^{\bullet}=\left\{v \in \mathfrak{V}: v=\lim _{t \rightarrow 0+} V^{t} v\right\} .
$$

Lemma 8. Every analytic semigroup $\left\{V^{t}: t>0\right\}$ satisfies $\operatorname{ker} V^{\bullet} \cap \operatorname{im} V^{\bullet}=\{0\}$.

Lemma 9. If $\left\{V^{t}: t>0\right\}$ is a strongly continuous and uniformly bounded semigroup then

$$
\operatorname{im} V^{\bullet}=\overline{\bigcup_{t>0} \operatorname{im} V^{t}}
$$

Theorem 3. If $M$ is an $(L, p)$-sectorial operator then $\operatorname{im} U^{\bullet}=\mathfrak{U}^{1}$ and $\operatorname{im} F^{\bullet}=\mathfrak{F}^{1}$.

Put $\tilde{U}^{t}=\left.U^{t}\right|_{\tilde{\mathfrak{U}}}$ and $\tilde{F}^{t}=\left.F^{t}\right|_{\tilde{\mathfrak{F}}}$.

Consider the images of the semigroups $U^{\bullet}$ and $F^{\bullet}$ :

$$
\operatorname{im} U^{\bullet}=\left\{u \in \mathfrak{U}: \lim _{t \rightarrow 0+} U^{t} u=u\right\}, \quad \operatorname{im} F^{\bullet}=\left\{f \in \mathfrak{F}: \lim _{t \rightarrow 0+} F^{t} f=f\right\} .
$$

Put $\mathfrak{U}^{1}=\operatorname{im} U^{\bullet}$ and $\mathfrak{F}^{1}=\operatorname{im} F^{\bullet}$. Denote by $L_{1}$ the restriction of $L$ to $\mathfrak{U}^{1}$, and by $M_{1}$ the restriction of $M$ to $\mathfrak{U}^{1} \cap \operatorname{dom} M$. 
Corollary 2. If $M$ is an $(L, p)$-sectorial operator then

$$
\tilde{P}=s-\lim _{t \rightarrow 0+} \tilde{U}^{t}, \quad \tilde{Q}=s-\lim _{t \rightarrow 0+} \tilde{F}^{t} .
$$

The operators

$$
P=s-\lim _{t \rightarrow 0+} U^{t} \in \mathcal{L}(\mathfrak{U}), \quad Q=s-\lim _{t \rightarrow 0+} F^{t} \in \mathcal{L}(\mathfrak{F}),
$$

whenever they exist, are called the units of the semigroups $\left\{U^{t}: t>0\right\}$ and $\left\{F^{t}: t>0\right\}$. It is not difficult to see that the units of semigroups are projectors.

Definition 5. An operator $M$ is called strongly $(L, p)$-sectorial on the right (on the left) whenever it is $(L, p)$-sectorial and for $\lambda, \mu_{0}, \mu_{1}, \ldots, \mu_{p} \in S_{\Theta}^{L}(M)$ we have

$$
\left\|R_{(\mu, p)}^{L}(M)(\lambda L-M)^{-1} M u\right\|_{\mathfrak{U}} \leq \frac{\operatorname{const}(u)}{|\lambda| \prod_{k=0}^{p}\left|\mu_{k}\right|}
$$

for arbitrary $u \in \operatorname{dom} M$ (respectively, there exists a dense linear subspace $\stackrel{\circ}{\mathfrak{F}}$ of $\mathfrak{F}$ such that

$$
\left\|M(\lambda L-M)^{-1} L_{(\mu, p)}^{L}(M) f\right\|_{\mathfrak{F}} \leq \frac{\operatorname{const}(f)}{|\lambda| \prod_{k=0}^{p}\left|\mu_{k}\right|}
$$

for arbitrary $f \in \stackrel{\circ}{\mathfrak{F}})$.

Remark 4. (i) If $M$ is an $(L, \sigma)$-bounded operator and $\infty$ is a removable singular point of the $L$-resolvent of $M$ then $M$ is a strongly $(L, 0)$-sectorial operator on the right and on the left.

(ii) If $M$ is an $(L, \sigma)$-bounded operator and $\infty$ is a pole of order at most $p$ then $M$ is a strongly $(L, p)$-sectorial operator on the right and on the left.

Theorem 4. If $M$ is a strongly $(L, p)$-sectorial operator on the right (on the left) then the units of the semigroups $\left\{U^{t}: t>0\right\}$ and $\left.\left\{F^{t}: t>0\right\}\right)$ exist. Furthermore, the operators $P \in \mathcal{L}(\mathfrak{U})$ and $Q \in \mathcal{L}(\mathfrak{F})$ satisfy

$$
L \in \mathcal{L}(\operatorname{ker} P ; \operatorname{ker} Q) \cap \mathcal{L}(\operatorname{im} P ; \operatorname{im} Q), \quad M \in \mathcal{C} l(\operatorname{ker} P ; \operatorname{ker} Q) \cap \mathcal{C} l(\operatorname{im} P ; \operatorname{im} Q) .
$$

Remark 5. Theorem 4 also holds in the case that $M$ is an $(L, p)$-sectorial operator, but under the additional requirements that the spaces $\mathfrak{U}$ and $\mathfrak{F}$ are reflexive (the Yagi-Fedorov theorem).

Corollary 3. If $M$ is a strongly $(L, p)$-sectorial operator on the right (on the left) then

$$
\mathfrak{U}^{0} \oplus \mathfrak{U}^{1}=\mathfrak{U}\left(\mathfrak{F}^{0} \oplus \mathfrak{F}^{1}=\mathfrak{F}\right) .
$$

Corollary 4. If $M$ is a strongly $(L, p)$-sectorial operator on the right and on the left then

(i) $\forall u \in \mathfrak{U} L P u=Q L u$;

(ii) $\forall u \in \operatorname{dom} M P u \in \operatorname{dom} M$ and $M P u=Q M u$.

Recall that $L_{k}=\left.L\right|_{\mathfrak{U}^{k}}$ and $M_{k}=\left.M\right|_{\operatorname{dom} M_{k}}$, while $\operatorname{dom} M_{k}=\operatorname{dom} M \cap \mathfrak{U}^{k}$ for $k=0,1$.

Corollary 5. If $M$ is a strongly $(L, p)$-sectorial operator on the right and on the left then $M_{0} \in$ $\mathcal{C l}\left(\mathfrak{U}^{0} ; \mathfrak{F}^{0}\right)$ is a bijective operator and $M_{1} \in \mathcal{C l}\left(\mathfrak{U}^{1} ; \mathfrak{F}^{1}\right)$. 


\section{Existence of the Inverse Operator}

On assuming that $\mathfrak{U}$ and $\mathfrak{F}$ are Banach spaces, take $L \in \mathcal{L}(\mathfrak{U} ; \mathfrak{F})$ and $M \in \mathcal{C l}(\mathfrak{U} ; \mathfrak{F})$.

We now indicate conditions for the existence of the operator $L_{1}^{-1} \in \mathcal{L}\left(\mathfrak{F}^{1} ; \mathfrak{U}^{1}\right)$. To this end, we use an integral of Dunford-Taylor type to define the family of operators $\left\{R^{t}: t>0\right\}$ as

$$
R^{t}=\frac{1}{2 \pi i} \int_{\Gamma}(\mu L-M)^{-1} e^{\mu t} d \mu,
$$

where the contour $\Gamma$ satisfies (16), while $M$ is an $(L, p)$-sectorial operator, and so the integral converges.

Lemma 10. If $M$ is an $(L, p)$-sectorial operator then the family $\left\{R^{t}: t>0\right\}$ defined in (18) is analytic in the sector $\{\tau \in \mathbf{C}:|\arg \tau|<\Theta-\pi / 2\}$.

Lemma 11. In the hypotheses of Lemma 10, we have

(i) $\forall t>0 R^{t} L=U^{t}$ and $L R^{t}=F^{t}$;

(ii) $\forall s, t>0 R^{s+t}=U^{s} R^{t}=R^{t} F^{s}$.

Lemma 12. If $M$ is a strongly $(L, p)$-sectorial operator on the right (on the left) then

(i) $\forall t>0 \quad R^{t}=P R^{t} \quad\left(R^{t}=R^{t} Q\right)$;

(ii) $\quad \overline{\bigcup_{t>o} \operatorname{im} R^{t}}=\mathfrak{U}^{1} \quad\left(\forall t>0 \quad \operatorname{ker} R^{t}=\mathfrak{F}^{0}\right)$.

We can also observe that, as in the case of semigroups, the images of the operators $R^{t}$ increase as $t$ decreases: $\operatorname{im} R^{s} \subset \operatorname{im} R^{t}$ for $s>t>0$ follows from claim (ii) of Lemma 11.

Definition 6. An operator $M$ is called strongly $(L, p)$-sectorial whenever it is strongly $(L, p)$ sectorial on the left and

$$
\forall \lambda, \mu_{0}, \ldots, \mu_{p} \in S_{\Theta}^{L}(M) \quad\left\|R_{(\mu, p)}^{L}(M)(\lambda L-M)^{-1}\right\|_{\mathcal{L}(\mathfrak{F} ; \mathfrak{L})} \leq \frac{\text { const }}{|\lambda| \prod_{k=0}^{p}\left|\mu_{k}\right|} .
$$

Remark 6. Every strongly $(L, p)$-sectorial operator $M$ is strongly $(L, p)$-sectorial on the right.

Remark 7. If the operator $L^{-1} \in \mathcal{L}(\mathfrak{F} ; \mathfrak{U})$ exists and the operator $T=M L^{-1}$ (or $S=L^{-1} M$ ) is sectorial then $M$ is a strongly $(L, p)$-sectorial operator. We can take $L[$ dom $M]$ as a dense linear subspace $\stackrel{\circ}{\mathfrak{F}}$ of $\mathfrak{F}$.

Remark 8. If $M$ is an $(L, \sigma)$-bounded operator and $\infty$ is an inessential singular point then $M$ is a strongly $(L, p)$-sectorial operator.

Lemma 13. If $M$ is a strongly $(L, p)$-sectorial operator then the family of operators $\left\{R^{t}: t>0\right\}$ defined in (18) is uniformly bounded.

Theorem 5. If $M$ is a strongly $(L, p)$-sectorial operator then

$$
\text { the operator } L_{1}^{-1} \in \mathcal{L}\left(\mathfrak{F}^{1} ; \mathfrak{U}^{1}\right) \text { exists. }
$$

Remark 9. Condition (19) holds provided that $M$ is a strongly $(L, p)$-sectorial operator or (17) is fulfilled and im $L_{1}=\mathfrak{F}^{1}$ (Banach's Theorem).

The restriction $\left\{U_{1}^{t}: t \geq 0\right\}\left(\left\{F_{1}^{t}: t \in \overline{\mathbf{R}_{+}}\right\}\right)$of the semigroup $\left\{U^{t}: t \geq 0\right\}\left(\left\{F^{t}: t \geq 0\right\}\right)$ to the subspace $\mathfrak{U}^{1}\left(\mathfrak{F}^{1}\right)$ is a nondegenerate analytic semigroup. 
Keep the above notation $S_{1}=L_{1}^{-1} M_{1}$ and $T_{1}=M_{1} L_{1}^{-1}$.

Corollary 6. In the hypotheses of Theorem 5, the operator $S_{1} \in \mathcal{C l}\left(\mathfrak{U}^{1}\right)\left(T_{1} \in \mathcal{C l}\left(\mathfrak{F}^{1}\right)\right)$ is an infinitesimal generator of the semigroup $\left\{U_{1}^{t}: t \geq 0\right\}\left(\left\{F_{1}^{t}: t \in \overline{\mathbf{R}_{+}}\right\}\right)$.

The Hille-Yosida-Feller-Miyadera-Phillips theorem immediately yields

Corollary 7. In the hypotheses of Theorem 5, the operator $S_{1}\left(T_{1}\right)$ is sectorial; furthermore, $\sigma^{L}(M)=\sigma\left(S_{1}\right)=\sigma\left(T_{1}\right)$.

\section{Generalized Splitting Theorem}

On assuming that $\mathfrak{U}$ and $\mathfrak{F}$ are Banach spaces, take $L \in \mathcal{L}(\mathfrak{U} ; \mathfrak{F})$ and $M \in \mathcal{C} l(\mathfrak{U} ; \mathfrak{F})$ so that $M$ is an $(L, p)$-sectorial operator. In addition, assume that

$$
\begin{gathered}
\sigma^{L}(M)=\bigcup_{j=0}^{n} \sigma_{j}^{L}(M), n \in \mathbb{N} \text {; furthermore, } \sigma_{j}^{L}(M) \neq \emptyset \\
\text { lies in a bounded region } D_{j} \subset \mathbb{C} \\
\text { with piecewise smooth boundary } \partial D_{j}=\Gamma_{j} \subset \mathbb{C}, j=\overline{1, n} \text {. } \\
\text { In addition, } \overline{D_{j}} \cap \sigma_{0}^{L}(M)=\emptyset \text { and } \overline{D_{k}} \cap \overline{D_{l}}=\emptyset \\
\text { for all } j, k, l=\overline{1, n}, k \neq l .
\end{gathered}
$$

Theorem 6. If $M$ is an (L,p)-sectorial operator and (20) holds then there exist projectors $P_{j} \in$ $\mathcal{L}(\mathfrak{U})$ and $Q_{j} \in \mathcal{L}(\mathfrak{F})$ for $j=\overline{1, n}$, which are of the form

$$
P_{j}=\frac{1}{2 \pi i} \int_{\Gamma_{j}} R_{\mu}^{L}(M) d \mu, Q_{j}=\frac{1}{2 \pi i} \int_{\Gamma_{j}} L_{\mu}^{L}(M) d \mu, j=\overline{1, n} .
$$

Corollary 8. The hypotheses of Theorems 4 and 6 yield $P_{j} P=P P_{j}=P_{j}$ and $Q_{j} Q=Q Q_{j}=Q_{j}$.

Put $P_{0}=P-\sum_{j=1}^{n} P_{j}$. Corollary 8 implies that $P_{0} \in \mathcal{L}(\mathfrak{U})$ is a projector.

Corollary 9. If $M$ is an (L,p)-sectorial operator then

(i) $L_{0} \in \mathcal{L}\left(\mathfrak{U}^{0} ; \mathfrak{F}^{0}\right)$ and $M_{0} \in \mathcal{C l}\left(\mathfrak{U}^{0} ; \mathfrak{F}^{0}\right)$, and moreover, the operator $M_{0}^{-1} \in \mathcal{L}\left(\mathfrak{F}^{0} ; \mathfrak{U}^{0}\right)$ exists;

(ii) $L_{1} \in \mathcal{L}\left(\mathfrak{U}^{1} ; \mathfrak{F}^{1}\right)$ and $M_{1} \in \mathcal{C l}\left(\mathfrak{U}^{1} ; \mathfrak{F}^{1}\right)$.

Assume now that, apart from (20), conditions (17) and (19) are fulfilled.

Corollary 10. If $M$ is an (L,p)-sectorial operator, while (17) and (19) hold, then $G=M_{0}^{-1} L_{0} \in$ $\mathcal{L}\left(\mathfrak{U}^{0}\right)$ is a degree $p$ nilpotent operator, while $S=L_{1}^{-1} M_{1} \in \mathcal{C l}\left(\mathfrak{U}^{1}\right)$ is a sectorial operator.

Theorem 7. If $M$ is an (L,p)-sectorial operator and (17), (19), and (20) hold then

$$
U^{t}=P_{j} U^{t}+P_{0} U^{t}=U_{j}^{t}+U_{0}^{t}, F^{t}=Q_{j} F^{t}+Q_{0} F^{t}=F_{j}^{t}+F_{0}^{t} ;
$$

furthermore, we can express $U_{j}^{t}$ and $F_{j}^{t}$ as

$$
U_{j}^{t}=\frac{1}{2 \pi i} \int_{\Gamma_{j}} R_{\mu}^{L}(M) e^{\mu t} d \mu, \quad F_{j}^{t}=\frac{1}{2 \pi i} \int_{\Gamma_{j}} L_{\mu}^{L}(M) e^{\mu t} d \mu, \quad j=\overline{1, n}
$$

where $\Gamma_{j}, j=\overline{1, n}$ is defined in (20). 
Proof. Indeed, since the analytic semigroup $U_{j}^{\bullet}$ extends to an analytic group, it follows that $U_{j}^{0}=P_{j}$. Hence,

$$
\begin{gathered}
P_{j} U^{t}=(2 \pi i)^{-1} \int_{\Gamma_{j}} \int_{\Gamma} R_{\mu}^{L}(M) R_{\nu}^{L}(M) e^{\nu t} d \mu d \nu= \\
=(2 \pi i)^{-1}\left(\int_{\Gamma} \frac{e^{\nu t} d \nu}{\nu-\mu} \int_{\Gamma_{j}} R_{\mu}^{L}(M) d \mu+\int_{\Gamma_{j}} \frac{d \mu}{\mu-\nu} \int_{\Gamma} R_{\mu}^{L}(M) e^{\nu t} d \nu\right)=U_{j}^{t}, \quad j=\overline{1, n},
\end{gathered}
$$

by the residue theorem and the analog of Hilbert's identity for the $L$-resolutions

$$
(\nu-\mu) R_{\mu}^{L}(M) R_{\nu}^{L}(M)=R_{\mu}^{L}(M)-R_{\nu}^{L}(M) .
$$

This also implies that $P_{j} P=P P_{j}=P_{j}$.

Put $\operatorname{im} P_{j}=\mathfrak{U}^{1 j}$ and $\operatorname{im} Q_{j}=\mathfrak{F}^{1 j}$ for $j=\overline{0, n}$. By construction,

$$
\mathfrak{U}^{1}=\bigoplus_{j=0}^{n} \mathfrak{U}^{1 j} \text { and } \mathfrak{F}^{1}=\bigoplus_{j=0}^{n} \mathfrak{F}^{1 j}
$$

Denote by $L_{j}\left(M_{j}\right)$ the restriction of $L(M)$ to $\mathfrak{U}_{j}\left(\operatorname{dom} M \cap \mathfrak{U}_{j}\right)$ for $j=\overline{0, n}$. By analogy with Corollary 9 , we can easily show that $L_{j} \in \mathcal{L}\left(\mathfrak{U}_{j} ; \mathfrak{F}_{j}\right)$ and $M_{j} \in \mathcal{C} l\left(\mathfrak{U}_{j} ; \mathfrak{F}_{j}\right)$ for $j=\overline{0, n}$. Furthermore, by (19) the operators $L_{j}^{-1} \in \mathcal{L}\left(\mathfrak{F}_{j} ; \mathfrak{U}_{j}\right)$ for $j=\overline{0, n}$ exist. Also, it is not difficult to show by analogy with Corollary 10 that $S_{0}=L_{0}^{-1} M_{0} \in \mathcal{C l}\left(\mathfrak{U}_{0}\right)$ is a sectorial operator, while $S_{j}=L_{j}^{-1} M_{j}: \mathfrak{U}_{j} \rightarrow \mathfrak{U}_{j}$ for $j=\overline{1, n}$ are bounded operators.

\section{Multipoint Initial-Final Value Problem for Sobolev-Type Equations with a Relatively $p$-sectorial Operator}

On assuming that $\mathfrak{U}$ and $\mathfrak{F}$ are Banach spaces, take $L \in \mathcal{L}(\mathfrak{U} ; \mathfrak{F})$ and $M \in \mathcal{C} l(\mathfrak{U} ; \mathfrak{F})$ so that $M$ is an $(L, p)$-sectorial operator. In addition, assume that conditions (17), (19), and (20) are fulfilled.

Taking $\tau_{j} \in \mathbb{R}_{+}\left(\tau_{j}<\tau_{j+1}\right), u_{j} \in \mathfrak{U}$ for $j=\overline{0, n}$, and $f \in C^{\infty}\left(\mathbb{R}_{+} ; \mathfrak{F}\right)$, consider the problem

$$
P_{j}\left(u\left(\tau_{j}\right)-u_{j}\right)=0, \quad j=\overline{0, n},
$$

for the linear Sobolev-type equation

$$
L \dot{u}=M u+f .
$$

Refer to a vector function $u \in C^{1}\left(\left(0, \tau_{n}\right) ; \mathfrak{U}\right) \cap C\left(\left[0, \tau_{n}\right] ; \mathfrak{U}\right)$ satisfying $(24)$ as its solution; refer to a solution $u=u(t)$ to $(24)$ as a solution to problem (23), (24) whenever $\lim _{t \rightarrow \tau_{0}+} P_{0}\left(u(t)-u_{0}\right)=0$ and $P_{j}\left(u\left(\tau_{j}\right)-u_{j}\right)=0$ for $j=\overline{1, n}$.

We are now ready to prove the unique solvability of problem (23) for (24). Since $M$ is an $(L, p)$-sectorial operator, while $(17),(19)$, and (20) hold, the problem reduces to

$$
\begin{gathered}
G \dot{u}^{0}=u^{0}+M_{0}^{-1} f^{0}, \\
\dot{u}^{1 j}=S_{j} u^{1 j}+L_{1 j}^{-1} f^{1 j}, j=\overline{0, n}
\end{gathered}
$$

where $f^{0}=(\mathbb{I}-Q) f$ and $f^{1 j}=Q_{j} f$, while $u^{0}=(\mathbb{I}-P) u$ and $u^{1 j}=P_{j} u$, for $j=\overline{1, n}$.

Lemma 14. If $M$ is an (L,p)-sectorial operator, while conditions (17), (19), and (20) are fulfilled, then for every vector function

$$
f^{0} \in C^{p}\left(\left[0, \tau_{n}\right] ; \mathfrak{F}^{0}\right) \cap C^{p+1}\left(\left(0, \tau_{n}\right) ; \mathfrak{F}^{0}\right)
$$


there exists a unique solution to (25); furthermore, it is of the form

$$
u^{0}(t)=-\sum_{q=1}^{p} G^{q} M_{0}^{-1} f^{0(q)}(t) .
$$

Proof. Substituting $u^{0}=u^{0}(t)$ into (25), we verify that a solution exists. The successive differentiation of the homogeneous equations (25),

$$
0=G^{p} u^{0(p)}=\ldots=G \dot{u}^{0}=u^{0},
$$

justifies uniqueness.

Lemma 15. In the hypotheses of Lemma 14, for all $u_{j} \in \mathfrak{U}$ and $f^{1 j} \in C\left(\left[0, \tau_{n}\right] ; \mathfrak{F}^{1 j}\right)$ there exists a unique solution to problem $u^{j}\left(\tau_{j}\right)=P_{j} u_{j}=0$ for the equation with index $j$ in (26); furthermore, it is of the form

$$
u^{1 j}(t)=U_{j}^{t-\tau_{j}} u_{j}+\int_{\tau_{j}}^{t} U_{j}^{t-s} L_{1 j}^{-1} Q_{j} f(s) d s
$$

Proof. By substitution, we verify that $u^{j}=u^{j}(t)$ is a solution to this problem. Suppose that $v^{j}=v^{j}(t)$ for $t \in\left[0, \tau_{n}\right]$ is another solution to this problem. Construct the vector function $w(s, t)=L_{j} U_{j}^{t-s} v(s)$. By construction,

$$
\frac{\partial w(s, t)}{\partial s}=L_{j} \frac{\partial U_{j}^{t-s}}{\partial s} v(s)+L_{j} U_{j}^{t-s} \frac{\partial v(s)}{\partial s}=0
$$

Hence, $w\left(\tau_{j}, t\right)=w(t, t)$, that is, $U_{j}^{t-\tau_{j}}$.

Theorem 8. If $M$ is an (L,p)-sectorial operator, while (17), (19), and (20) hold, then for every vector function with $f^{0} \in C^{p}\left(\left[0, \tau_{n}\right] ; \mathfrak{F}^{0}\right) \cap C^{p+1}\left(\left(0, \tau_{n}\right) ; \mathfrak{F}^{0}\right)$ and $f^{1} \in C\left(\left[0, \tau_{n}\right] ; \mathfrak{F}^{1}\right)$ there exists a unique solution to problem (23), (24); furthermore, it is of the form

$$
u(t)=u^{0}(t)+\sum_{j=1}^{n} u^{j}(t) .
$$

\section{The Linear Model of Plane-Parallel Thermal Convection in Viscoelastic Incompressible Fluid}

Consider the linear model

$$
(\lambda-\Delta) \Delta \psi_{t}=\nu \Delta \psi-\alpha \theta_{x}+\xi, \quad \theta_{t}=\delta \Delta \theta-\beta \psi_{x}+\zeta
$$

of plane-parallel thermal convection in viscoelastic incompressible fluid in the region $\Omega=(0, a) \times$ $(0, b) \in \mathbb{R}^{2}$ with Bénard's boundary conditions

$$
\begin{gathered}
\psi(x, 0, t)=\Delta \psi(x, 0, t)=\psi(x, h, t)=\Delta \psi(x, h, t)=0, \\
\theta(x, 0, t)=\theta(x, h, t)=0,
\end{gathered}
$$

the functions $\psi$ and $\theta$ are periodic in $x$ with period $l$. 
Put $\mathfrak{U}=\mathfrak{V} \times \mathfrak{W}$ and $\mathfrak{F}=\mathfrak{G} \times \mathfrak{H}$, where $\mathfrak{V}=\left\{v \in W_{2}^{4}(\Omega): v\right.$ satisfies (28), (30 $\}$ and $\mathfrak{W}=\mathfrak{G}=\mathfrak{H}=L_{2}(\Omega)$. Define $L$ and $M$ as

$$
L=\left(\begin{array}{cc}
(\lambda-\Delta) \Delta & 0 \\
0 & \mathbb{I}
\end{array}\right), \quad M=\left(\begin{array}{cc}
\nu \Delta^{2} & \alpha \frac{\partial}{\partial x} \\
\beta \frac{\partial}{\partial x} & \delta \Delta
\end{array}\right)
$$

It is obvious that $L \in \mathcal{L}(\mathfrak{U} ; \mathfrak{F})$, while $M \in \mathcal{C l}(\mathfrak{U} ; \mathfrak{F})$ with

$$
\operatorname{dom} M=\mathfrak{V} \times\left\{w \in W_{2}^{2}(\Omega): w \text { satisfies }(28) \text { and }(29)\right\} .
$$

In order to prove that $M$ is an $(L, 0)$-sectorial operator, consider the eigenfunctions of the Laplace operator $\Delta$ on $\Omega$ satisfying (28) and (30). It is convenient to split these eigenfunctions into three families:

$$
F_{1}=\left\{\cos \frac{2 \pi m x}{a} \sin \frac{\pi n y}{b}\right\}, \quad F_{2}=\left\{\sin \frac{2 \pi k x}{a} \sin \frac{\pi l y}{b}\right\}, \quad F_{3}=\left\{\sin \frac{\pi j x}{b}\right\},
$$

where $j, k, l, m, n \in \mathbb{N}$. Henceforth we denote the normalized functions in each family by $\varphi_{m n}^{1}$, $\varphi_{k l}^{2}$, and $\varphi_{j}^{3}$, while the corresponding eigenvalues by $\lambda_{m n}^{1}, \lambda_{k l}^{2}$, and $\lambda_{j}^{3}$. To construct the operator $(\mu L-M)^{-1}$ we apply Fourier's method: expand the functions $v, w, g$, and $h$ into Fourier series with respect to the functions $\left\{\varphi_{m n}^{1}\right\} \cup\left\{\varphi_{k l}^{2}\right\} \cup\left\{\varphi_{j}^{3}\right\}$ and insert the resulting series into the system

$$
\mu(\lambda-\Delta) \Delta v-\nu \Delta v-\alpha w_{x}=g, \quad(\mu-\delta \Delta) w-\beta v_{x}=h .
$$

Applying a series of orthogonal projectors yields blocks of six equations:

$$
\begin{aligned}
& \lambda_{m n}^{1}\left[\mu\left(\lambda-\lambda_{m n}^{1}\right)-\nu \lambda_{m n}^{1}\right] v_{m n}^{1}-\alpha \frac{\pi m}{a} w_{m n}^{2}=g_{m n}^{1}, \\
& \lambda_{k l}^{2}\left[\mu\left(\lambda-\lambda_{k l}^{2}\right)-\nu \lambda_{k l}^{2}\right] v_{k l}^{2}+\alpha \frac{\pi k}{a} w_{k l}^{1}=g_{k l}^{2}, \\
& \lambda_{j}^{3}\left[\mu\left(\lambda-\lambda_{j}^{3}\right)-\nu \lambda_{j}^{3}\right] v_{j}^{3}=g_{j}^{3}, \\
& \left(\mu-\delta \lambda_{m n}^{1}\right) w_{m n}^{1}-\beta \frac{\pi m}{a} w_{m n}^{2}=h_{m n}^{1}, \\
& \left(\mu-\delta \lambda_{k l}^{2}\right) w_{k l}^{2}+\beta \frac{\pi k}{a} v_{k l}^{1}=h_{k l}^{2}, \\
& \left(\mu-\delta \lambda_{j}^{3}\right) w_{j}^{3}=h_{j}^{3} .
\end{aligned}
$$

To solve this system, observe firstly that without loss of generality we may take $k=m$ and $l=n$. Observe in addition that $\lambda_{m n}^{1}=\lambda_{m n}^{2}$; therefore, put $\lambda_{m n}^{1}=\lambda_{m n}^{2}=\lambda_{m n}$. Solving (31), we obtain the $L$-resolvent of $M$ as the square matrix $A=\left\|A_{i j}\right\|_{i, j=1}^{6}$ whose entries we can express as

$$
\begin{aligned}
& A_{11}=\sum_{m, n} \Delta_{m n} \lambda_{m n}\left[\mu\left(\lambda-\lambda_{m n}\right)-\nu \lambda_{m n}\right]\left\langle\cdot, \varphi_{m n}^{1}\right\rangle \varphi_{m n}^{1}, A_{15}=\sum_{m, n} \Delta_{m n} a^{-1} \alpha \pi m\left\langle\cdot, \varphi_{m n}^{2}\right\rangle \varphi_{m n}^{1}, \\
& A_{22}=\sum_{m, n} \Delta_{m n} \lambda_{m n}\left[\mu\left(\lambda-\lambda_{m n}\right)-\nu \lambda_{m n}\right]\left\langle\cdot, \varphi_{m n}^{2}\right\rangle \varphi_{m n}^{2}, A_{24}=-\sum_{m, n} \Delta_{m n} a^{-1} \alpha \pi m\left\langle\cdot, \varphi_{m n}^{1}\right\rangle \varphi_{m n}^{2}, \\
& A_{33}=\sum_{j} \frac{\left\langle\cdot, \varphi_{j}\right\rangle \varphi_{j}}{\lambda_{j}\left[\mu\left(\lambda-\lambda_{j}\right)-\nu \lambda_{j}\right]}, A_{42}=\sum_{m, n} \Delta_{m n} \beta a^{-1} \pi m\left\langle\cdot, \varphi_{m n}^{2}\right\rangle \varphi_{m n}^{1}, \\
& A_{44}=\sum_{m, n} \Delta_{m n}\left(\mu-\delta \lambda_{m n}^{1}\right)\left\langle\cdot, \varphi_{m n}^{1}\right\rangle \varphi_{m n}^{1}, A_{51}=-\sum_{m, n} \Delta_{m n} \beta a^{-1} \pi m\left\langle\cdot, \varphi_{m n}^{1}\right\rangle \varphi_{m n}^{2}, \\
& A_{55}=\sum_{m, n} \Delta_{m n}\left(\mu-\delta \lambda_{m n}\right)\left\langle\cdot, \varphi_{m n}^{2}\right\rangle \varphi_{m n}^{2}, A_{66}=\sum_{j} \frac{\left\langle\cdot, \varphi_{j}\right\rangle \varphi_{j}}{\mu-\delta \lambda_{j}} .
\end{aligned}
$$


Here $\Delta_{m n}^{-1}=\lambda_{m n}\left[\mu\left(\lambda-\lambda_{m n}\right)-\nu \lambda_{m n}\right]\left(\mu-\delta \lambda_{m n}\right)+\alpha \beta a^{-2} \pi^{2} m^{2}$ and $\lambda_{j}=\lambda_{j}^{3}$, while all remaining matrix entries are equal to the zero operator $\mathbb{O}$. This implies, firstly, that the $L$-spectrum of $M$ is

$$
\sigma^{L}(M)=\left\{\frac{\nu \lambda_{m n}}{\lambda-\lambda_{m n}}+\varepsilon_{m n}\right\} \cup\left\{\delta \lambda_{m n}-\varepsilon_{m n}\right\} \cup\left\{\frac{\nu \lambda_{j}}{\lambda-\lambda_{j}}\right\} \cup\left\{\delta \lambda_{j}\right\}
$$

Here

$$
\left|\varepsilon_{m n}\right| \sim \sqrt{\left|\frac{m^{2}}{\lambda_{m n}\left(\lambda-\lambda_{m n}\right)}\right|}
$$

as $m, n \rightarrow \infty$, and since $\lambda_{m n} \sim-m^{2}-n^{2}$ as $m, n \rightarrow \infty$, it follows that there exists a sector of the required opening angle which includes $\sigma^{L}(M)$. Secondly, for sufficiently large $|\mu|$ outside this sector we have

$$
\max \left\{\left\|R_{\mu}^{L}(M)\right\|_{\mathcal{L}(\mathfrak{U})},\left\|L_{\mu}^{L}(M)\right\|_{\mathcal{L}(\mathfrak{F})},\right\} \leq \text { const }|\mu|^{-1} .
$$

This justifies

Lemma 16. For all $\alpha, \beta, \lambda, \nu \in \mathbb{R}$ and $\delta \in \mathbb{R}_{+}$, the operator $M$ is $(L, 0)$-sectorial.

Let us now verify (17) and (19) Since $\mathfrak{U}$ and $\mathfrak{F}$ are reflexive spaces, Lemma 16 and the Yagi-Fedorov theorem imply that condition (17) is fulfilled. Furthermore,

(i) $\mathfrak{U}^{0}=\mathfrak{F}^{0}=\{0\}, \mathfrak{U}^{1}=\mathfrak{U}$, and $\mathfrak{F}^{1}=\mathfrak{F}$ if $\lambda \neq \lambda_{m n}$ and $\lambda \neq \lambda_{j}$;

(ii) $\mathfrak{U}^{0}=\mathfrak{F}^{0}=\operatorname{ker} L=\operatorname{span}\left\{\operatorname{col}\left(\varphi_{j}, 0\right)\right\}, \mathfrak{U}^{1}=\left\{u \in \mathfrak{U}:\left\langle u, \varphi_{j}\right\rangle=0\right\}$, and $\mathfrak{F}^{1}=\{f \in \mathfrak{F}$ : $\left.\left\langle g, \varphi_{j}\right\rangle=0\right\}=\operatorname{im} L$ if $\lambda \neq \lambda_{m n}$ and $\lambda=\lambda_{j}$

(iii) $\mathfrak{U}^{0}=\mathfrak{F}^{0}=\operatorname{ker} L=\operatorname{span}\left\{\operatorname{col}\left(\varphi_{m n}^{1}, 0\right), \operatorname{col}\left(\varphi_{m n}^{2}, 0\right)\right\}, \mathfrak{F}^{1}=\left\{f \in \mathfrak{F}:\left\langle g, \varphi_{m n}^{k}\right\rangle=\right.$ $0, k=1,2\}=\operatorname{im} L, \mathfrak{U}^{1}=\left\{u \in \mathfrak{U}: v=\bar{v}+v_{m n}(w),\left\langle\bar{v}, \varphi_{m n}^{k}\right\rangle=0, k=1,2, v_{m n}(w)=\right.$ $\left.=2 \pi m a^{-1} \nu^{-1} \lambda_{m n}^{-2}\left(\left\langle w, \varphi_{m n}^{1}\right\rangle \varphi_{m n}^{2}+\left\langle w, \varphi_{m n}^{2}\right\rangle \varphi_{m n}^{1}\right)\right\}$ if $\lambda=\lambda_{m n}$ and $\lambda \neq \lambda_{j}$.

Condition (19) is also fulfilled; furthermore, we can express the operator $L_{1}^{-1}$ as the square matrix $A=\left\|A_{i j}\right\|_{i, j=1}^{2}$ with

$$
\begin{gathered}
A_{11}=\sum_{m, n} \frac{\left\langle\cdot, \varphi_{m n}^{1}\right\rangle \varphi_{m n}^{1}}{\lambda_{m n}\left(\lambda-\lambda_{m n}\right)}+\sum_{m, n}{ }^{\prime} \frac{\left\langle\cdot, \varphi_{m n}^{2}\right\rangle \varphi_{m n}^{2}}{\lambda_{m n}\left(\lambda-\lambda_{m n}\right)}+\sum_{j}{ }^{\prime} \frac{\left\langle\cdot, \varphi_{j}\right\rangle \varphi_{j}}{\lambda_{j}\left(\lambda-\lambda_{j}\right)}, \\
A_{21}=V_{m n}, A_{21}=\mathbb{O}, A_{22}=\mathbb{I},
\end{gathered}
$$

where

$$
V_{m n}=\left\{\begin{array}{l}
\mathbb{O} \text { if } \lambda=\lambda_{m n}, \\
\alpha \pi m a^{-1} \nu^{-1} \lambda_{m n}^{-2}\left(\left\langle\cdot, \varphi_{m n}^{1}\right\rangle \varphi_{m n}^{2}+\left\langle\cdot, \varphi_{m n}^{2}\right\rangle \varphi_{m n}^{1}\right) \text { if } \lambda \neq \lambda_{m n} .
\end{array}\right.
$$

The prime on the sum symbol indicates that the terms with $\lambda=\lambda_{m n}$ or $\lambda=\lambda_{j}$ are absent. This justifies

Lemma 17. Conditions (17) and (19) are fulfilled for all $\alpha, \beta, \lambda, \nu \in \mathbb{R}$, and $\delta \in \mathbb{R}_{+}$.

By (32), the $L$-spectrum $\sigma^{L}(M)$ of $M$ is discrete. This means that the hypotheses of Theorem 6 hold as well; moreover, they do for every closed contour $\gamma \in \mathbb{C}$ bounding a region which contains finitely many points of $\sigma^{L}(M)$ and is disjoint from $\sigma^{L}(M)$. Therefore, the hypotheses of Theorem 8 hold, and so we have

Theorem 9. For all $\alpha, \beta, \lambda, \nu \in \mathbb{R}, \delta, \tau_{j} \in \mathbb{R}_{+}, u_{j} \in \mathfrak{U}$ for $j=\overline{0, n}$, and $\xi, \zeta \in C^{1}\left(\left[0, \tau_{n}\right] ; L_{2}(\Omega)\right)$ there exists a unique solution to problem (23) for (27) with boundary conditions (28)-(30).

The author is grateful to Professor G. A. Sviridyuk for fruitful discussions and interest in this work. 


\section{References}

1. Dudko L.L. Issledovanie polugrupp operatorov s yadrami: dis. ... kand. fiz.-mat. nauk [Investigation of Semigroups of Operators with Kernels]. Novgorod, 1996. (in Russian)

2. Zagrebina S.A. On the Showalter - Sidorov problem. Russian Mathematics (Izvestiya VUZ. Matematika), 2007, vol. 51, no. 3, pp. 19-24.

3. Zagrebina S.A. The Showalter - Sidorov - Verigin Problem for the Linear Sobolev-type Equations. Neklassicheskie uravneniya matematicheskoy fiziki [Nonclassical Mathematical Physics equations], Novosibirsk, 2007, pp. 150-157. (in Russian)

4. Zagrebina S.A., Yakupov M.M. Existence and Stability of Solutions of one Class of Semilinear Sobolev Type Equations. Bulletin of the South Ural State University. Series "Mathematical Modelling, Programming \& Computer Software", 2008, no. 27 (127), issue 2, pp. 10-18. (in Russian)

5. Zagrebina S.A. The Multipoint Initial-Finish Problem for the Stochastic Barenblatt - Zheltov - Kochina Model. Bulletin of the South Ural State University. Series "Computer Technologies, Automatic Control, Radio Electronics", 2013, vol. 13, no. 4, pp. 103-111. (in Russian)

6. Zamyshlyaeva A.A., Tsyplenkova O.N. The Optimal Control over Solutions of the Initialfinish Value Problem for the Boussinesque-Löve Equation Bulletin of the South Ural State University. Series "Mathematical Modelling, Programming 8 Computer Software", 2012, vol. 5 (264), issue 11, pp. 13-24. (in Russian)

7. Keller A.V. The Algorithm for Solution of the Showalter - Sidorov Problem for Leontief Type Models. Bulletin of the South Ural State University. Series "Mathematical Modelling, Programming \&5 Computer Software", 2012, no. 4 (241), issue 7, pp. 40-46. (in Russian)

8. Landau L.D., Lifshitz E.M. Fluid Mechanics. Oxford, Pergamon Press, 1959.

9. Manakova N.A., Dylkov A. G. Optimal Control of the Solutions of the Initial-Finish Problem for the Linear Hoff Model. Mathematical Notes, 2013, vol. 94, issue 2, pp. 220-230. DOI: $10.1134 /$ S0001434613070225

10. Matveeva O.P., Sukacheva T.G. Matematicheskie modeli vyazkouprugikh neszhimaemykh zhidkostey nenulevogo poryadka [The mathematical model of a viscoelastic incompressible fluid of nonzero order]. Chelyabinsk, Publishing center of South Ural State University, 2014. (in Russian)

11. Oskolkov A. P. Nonlocal Problems for Some Class Nonlinear Operator Equations Arising in the Theory Sobolev Type Equations. Zap. Nauchn. Sem. LOMI, 1991, vol. 198, pp. 31-48. (in Russian)

12. Pankov A.A., Pankova T.E. Nonlinear Evolution Equations with Irreversible Operator Coefficient for the Derivative. Doklady Akademii Nauk Ukraine, 1993, no. 9, pp. 18-20. (in Russian)

13. Sviridyuk G.A. Solvability of a Problem of the Thermoconvection of a Viscoelastic Incompressible Fluid. Soviet Mathematics (Izvestiya VUZ. Matematika), 1990, vol. 34, no. 12, pp. $80-86$.

14. Sviridyuk G.A. Semilinear Equations of Sobolev Type with a Relatively Sectorial Operator. Doklady Mathematics, 1993, vol. 329, no. 3, pp. 274-277.

15. Sviridyuk G.A. Phase Portraits of Sobolev-Type Semilinear Equations with a Relatively Strongly Sectorial Operator. St. Petersburg Mathematical Journal, 1995, vol. 6, no. 5, pp. $1109-1126$.

16. Sviridyuk G.A., Bokareva T.A. The Number of Deborah and One Class Semilinear Equations of Sobolev Type, Doklady Mathematics , 1991, vol. 319, no. 5, pp. 1082-1086. 
17. Sviridyuk G.A., Efremov A.A. Optimal Control Of Sobolev-Type Linear Equations With Relatively p-Sectorial Operators. Differential Equations, 1995, vol. 31, no. 11, pp. 1882-1890.

18. Sviridyuk G.A., Zagrebina S.A. On the Verigin Problem for the Generalized Boussinesq Filtration Equation. Russian Mathematics (Izvestiya VUZ. Matematika), 2003, vol. 47, no. 7, pp. $55-59$.

19. Sviridyuk G.A., Zagrebina S.A. Verigin's Problem for Linear Equations of the Sobolev Type with Relatively p-Sectorial Operators. Differential Equations, 2002, vol. 38, no. 12, pp. 1745-1752. DOI: 10.1023/A:1023812213901

20. Sviridyuk G.A., Zagrebina S.A. The Showalter - Sidorov Problem as a Phenomena of the Sobolev-Type Equations. The Bulletin of Irkutsk State University. Series "Mathematics", 2010, vol. 3, no. 1, pp. 51-72. (in Russian)

21. Sviridyuk G.A., Keller A.V. Invariant Spaces and Dichotomies of Solutions of a Class of Linear Equations of the Sobolev Type. Russian Mathematics (Izvestiya VUZ. Matematika), 1997, vol. 41, no. 5, pp. 57-65.

22. Sviridyuk G.A., Kuznetsov G.A. Relatively Strongly p- Sectorial Linear Operators. Doklady Mathematics, 1999, vol. 59, no. 2, pp. 298-300.

23. Sviridyuk G.A., Sukacheva T.G. Some Mathematical Problems of Dynamics Viscoelastic Incompressible Media. Vestnik Magnitogorskogo gosudarstvennogo universiteta. Seria «Matematika» [Bulletin of Magnitogorsk State University. Series «Mathematics»], 2005, issue 8, pp. 5-33. (in Russian)

24. Sviridyuk G.A., Fedorov V. E. Analytic Semigroups with Kernel and Linear Equations of Sobolev Type. Siberian Mathematical Journal, 1995, vol. 36, no. 5, pp. 973-987. DOI: $10.1007 / \mathrm{BF} 02112539$

25. Sviridyuk G.A., Fedorov V.E. On Units of Analytic Semigroups of Operators with Kernels. Siberian Mathematical Journal, 1998, vol. 39, no. 3, pp. 522-533. DOI: 10.1007/BF 02673910

26. Sviridyuk G.A., Yakupov M.M. The Phase Space Of The Initial-Boundary Value Problem For The Oskolkov System. Differential Equations, 1996, vol. 32, no. 11, pp. 1535-1540.

27. Sukacheva T.G., Matveeva O.P. Spline Approximations of the Solution of a Singular IntegroDifferential Equation. Russian Mathematics (Izvestiya VUZ. Matematika), 2001, vol. 45, no. 11 , pp. $44-51$.

28. Henry, D. Geometric Theory of Semilinear Parabolic Equations. Berlin, Heidelberg, N.-Y., Springer Verlag, 1981.

29. Shestakov A.L., Keller A.V., Nazarova E.I. The Numerical Solution of the Optimal Demension Problem. Automation and Remote Control, 2011, vol. 73, no. 1, pp. 97-104. DOI: $10.1134 /$ S0005117912010079

30. Al'shin, A.B., Korpusov, M.O., Sveshnikov, A.G. Blow-up in Nonlinear Sobolev Type Equations. Berlin, Walter de Gruyter GmbH\& Co.KG, 2011.

31. Demidenko G.V., Uspenskii S.V. Partial Differential Equations and Systems not Solvable with Respect to the Highest Order Derivative. N.-Y., Basel, Hong Kong, Marcel Dekker, Inc., 2003.

32. Pyatkov S.G. Operator Theory. Nonclassical Problems. Utrecht, Boston, Köln, Tokyo, VSP, 2002. DOI: $10.1515 / 9783110900163$

33. Showalter R.E. The Sobolev Type Equations. I (II). Appl. Anal., 1975, vol. 5, no. 1, pp. 15-22 (no. 2, pp. 81-89). 
34. Zagrebina S.A., Sagadeeva M.A. The Generalized Splitting Theorem for Linear Sobolev type Equations in Relatively Radial Case. The Bulletin of Irkutsk State University. Series "Mathematics", 2014, vol. 7, pp. 19-33.

\title{
МНОГОТОЧЕЧНАЯ НАЧАЛЬНО-КОНЕЧНАЯ ЗАДАЧА ДЛЯ ЛИНЕЙНОЙ МОДЕЛИ ПЛОСКОПАРАЛЛЕЛЬНОЙ ТЕРМОКОНВЕКЦИИ ВЯЗКОУПРУГОЙ НЕСЖИМАЕМОЙ ЖИДКОСТИ
}

\author{
С.А. Загребина
}

\begin{abstract}
Линейная модель плоскопараллельной термоконвекции вязкоупругой несжимаемой среды Кельвина - Фойгта представляет собой гибрид системы уравнений Осколкова и уравнения теплопроводности в приближении Обербека - Буссинеска, заданных в двумерной области с условиями Бенара. Целью нашего исследования является разрешимость этой модели с так называемыми многоточечными начально-конечными условиями. Такие условия используются для восстановления параметров изучаемых процессов по результатам многочисленных наблюдений с различных точек и в различные моменты времени, что позволяет, например, прогнозировать аварийные ситуации, в том числе нарушение непрерывности процесса термоконвекции в результате нарушения технологии и т.п.

Ранее для моделей термоконвекции изучалась разрешимость задач Коши и начально-конечной, кроме того, была рассмотрена устойчивость решений задачи Коши. Многоточечная начально-конечная задача для этой модели изучается впервые. Кроме того, в данной работе приводится доказательство обобщенной теоремы о расщеплении в случае относительно секториального оператора. Основной результат статьи - теорема об однозначной разрешимости многоточечной начально-конечной задачи для линейной модели плоскопараллельной термоконвекции вязкоупругой несжимаемой жидкости.

Ключевые слова: многоточечная начально-конечная задача; уравнение соболевского типа; обобщенная теорема о расщеплении; линейная модель плоскопараллельной термоконвекции вязкоупругой несжимаемой жидкости.
\end{abstract}

\section{Литература}

1. Дудко, Л.Л. Исследование полугрупп операторов с ядрами: дис. ... канд. физ.-мат. наук / Л.Л. Дудко. - Новгород, 1996.

2. Загребина, С.А. О задаче Шоуолтера - Сидорова / С.А. Загребина // Известия вузов. Математика. - 2007. - №3. - С. 22-28.

3. Загребина, С.А. Задача Шоуолтера - Сидорова - Веригина для линейных уравнений соболевского типа // Неклассические уравнения математической физики: тр. междунар. конф. «Дифференциальные уравнения, теория функций и приложения», посвящ. 100-летию со дня рождения акад. И. Н. Векуа / отв. ред. А. И. Кожанов; Рос. Акад. наук, Сиб. отд., ин-т математики им. С.Л. Соболева. - Новосибирск, 2007. - С. 150-157.

4. Загребина, С.А. Существование и устойчивость решений одного класса полулинейных уравнений соболевского типа / С.А. Загребина, М.М. Якупов // Вестник ЮУрГУ. Серия: Математическое моделирование и программирование. - Челябинск, 2008. № 27 (127), вып. 2. - С. 10-18. 
5. Загребина, С.А. Многоточечная начально-конечная задача для стохастической модели Баренблатта - Желтова - Кочиной / С.А. Загребина // Вестник ЮУрГУ. Серия: Компьютерные технологии, управление, радиоэлектроника. - Челябинск, 2013. - Т. 13, №4. - C. $103-111$.

6. Замышляева, А.А. Оптимальное управление решениями начально-конечной задачи для уравнения Буссинеска - Лява / А.А. Замышляева, О.Н. Цыпленкова // Вестник ЮУрГУ. Серия: Математическое моделирование и программирование. - Челябинск, 2012. №5 (264), вып. 11. - С. 13-24.

7. Келлер А.В. Алгоритм решения задачи Шоуолтера - Сидорова для моделей леонтьевского типа / А.В. Келлер // Вестник ЮУрГУ. Серия: Математическое моделирование и программирование. - Челябинск, 2012. - № 4 (241), вып. 7. - С. 40-46.

8. Landau L.D. Fluid Mechanics / L.D. Landau, E.M. Lifshitz. - Oxford: Pergamon Press, 1959 .

9. Манакова, Н.А. Оптимальное управление решениями начально-конечной задачи для линейной модели Хоффа / Н.А. Манакова, А.Г. Дыльков // Математические заметки. - 2013. - Т. 94, № 2. - С. 225-236.

10. Матвеева О.П. Математические модели вязкоупругих несжимаемых жидкостей ненулевого порядка: монография / О.П.Матвеева, Т.Г. Сукачева. - Челябинск: Изд. центр ЮУрГУ, 2014.

11. Осколков, А.П. Нелокальные проблемы для одного класса нелинейных операторных уравнений, возникающих в теории уравнений типа С.Л. Соболева / А.П. Осколков // Записки научных семинаров ЛОМИ. - 1991. - Т. 198. - С. 31-48.

12. Панков, А.А. Нелинейные эволюционные уравнения с необратимым операторным коэффициентом при производной / А. А. Панков, Т.Е. Панкова // Доклады Академии наук Украины. - 1993. - № 9. - С. 18-20.

13. Свиридюк, Г.А. Разрешимость задачи термоконвекции вязкоупругой несжимаемой жидкости / Г.А. Свиридюк // Известия вузов. Математика. - 1990. - № 12. - С. 65-70.

14. Свиридюк, Г.А. Полулинейные уравнения типа Соболева с относительно секториальным оператором / Г.А. Свиридюк // Доклады Академии наук СССР. - 1993. - Т. 329, №3. C. $274-277$.

15. Свиридюк, Г.А. Фазовые пространства полулинейных уравнений типа Соболева с относительно сильно секториальным оператором // Алгебра и анализ. - 1994. - Т. 6, №5. C. $252-272$.

16. Свиридюк, Г.А. Число Деборы и один класс полулинейных уравнений типа Соболева / Г.А. Свиридюк, Т.А. Бокарева // Доклады Академии наук СССР. - 1991. - Т. 319, № 5. - C. $1082-1086$.

17. Свиридюк, Г.А. Оптимальное управление линейными уравнениями типа Соболева с относительно р-секториальными операторами / Г.А. Свиридюк, А.А. Ефремов // Дифференциальные уравнения. - 1995.- Т. 31, № 11.- С. 1912-1919.

18. Свиридюк, Г.А. О задаче Веригина для обобщенного фильтрационного уравнения Буссинеска / Г.А. Свиридюк, С.А. Загребина // Известия вузов. Математика. - 2003. - № 7. - C. $54-58$.

19. Свиридюк, Г.А. Задача Веригина для линейных уравнений соболевского типа с относительно $p$-секториальными операторами / Г.А. Свиридюк, С.А. Загребина // Дифференциальные уравнения. - 2002. - Т. 38, № 12. - С. 1646-1652. 
20. Свиридюк, Г.А. Задача Шоуолтера - Сидорова как феномен уравнений соболевского типа / Г.А. Свиридюк, С.А. Загребина // Известия Иркутского государственного университетата. Серия: Математика. - 2010. - Т. 3, № 1. - С. 104-125.

21. Свиридюк, Г.А. Инвариантные пространства и дихотомии решений одного класса линейных уравнений типа Соболева / Г.А. Свиридюк, А.В. Келлер // Известия вузов. Математика. - 1997. - № 5. - С. 60-68.

22. Свиридюк, Г.А. Об относительно сильной $p$-секториальности линейных операторов / Г.А. Свиридюк, Г.А. Кузнецов // Доклады Академии наук. - 1999. - Т. 365, № 6. C. $736-738$.

23. Свиридюк, Г.А. Некоторые математические задачи динамики вязкоупругих несжимаемых сред / Г.А. Свиридюк, Т.Г. Сукачева // Вестник Магнитогорского государственного университета. Серия: Математика. - Магнитогорск, 2005. - Вып. 8. - С. 5-33.

24. Свиридюк, Г.А. Аналитические полугруппы с ядрами и линейные уравнения типа Соболева / Г.А. Свиридюк, В.Е. Федоров // Сибирский математический журнал. - 1995. - Т. 36, № 5. - C. 252-272.

25. Свиридюк, Г.А. О единицах аналитических полугрупп операторов с ядрами / Г.А. Свиридюк, В.Е. Федоров // Сибирский математический журнал. - 1998. - Т. 39, №3. C. 604-612.

26. Свиридюк, Г.А. Фазовое пространство начально-краевой задачи для системы Осколкова / Г.А. Свиридюк, М.М. Якупов // Дифференциальные уравнения. - 1996. - Т. 32, №11. - C. $1538-1543$.

27. Сукачева, Т.Г. Задача термоконвекции несжимаемой вязкоупругой жидкости Кельвина - Фойгта ненулевого порядка / Т.Г. Сукачева, О.П. Матвеева // Известия вузов. Математика. - 2001. - № 11. - С. 46-53.

28. Henry, D. Geometric Theory of Semilinear Parabolic Equations / D. Henry. - Berlin; Heidelberg; N.-Y.: Springer Verlag, 1981.

29. Шестаков, А.Л. Численное решение задачи оптимального измерения / А.Л. Шестаков, А.В. Келлер, Е.И. Назарова // Автоматика и телемеханика. - 2011. - № 12. - С. 56-68.

30. Al'shin, A.B. Blow-up in Nonlinear Sobolev Type Equations / A.B. Al'shin, M.O. Korpusov, A.G. Sveshnikov. - Berlin: Walter de Gruyter GmbH\& Co.KG, 2011.

31. Demidenko, G.V. Partial Differential Equations and Systems not Solvable with Respect to the Highest-order Derivative / G.V. Demidenko, S.V. Uspenskii. - N.-Y.; Basel; Hong Kong: Marcel Dekker, Inc., 2003.

32. Pyatkov, S.G. Operator Theory. Nonclassical Problems / S.G. Pyatkov. - Utrecht; Boston; Köln; Tokyo: VSP, 2002.

33. Showalter, R.E. The Sobolev Type Equations. I (II) / R.E. Showalter // Appl. Anal. - 1975. - V. 5, № 1. - P. 15-22 (№ 2. - P. 81-89).

34. Zagrebina S.A. The Generalized Splitting Theorem for Linear Sobolev type Equations in Relatively Radial Case / S.A. Zagrebina, M.A. Sagadeeva // Известия Иркутского государственного университета. Серия: Математика. - 2014. - Т. 7. - С. 19-33.

Софья Александровна Загребина, кафедра «Дифференциальные и стохастические уравнения, Южно-Уральский государственный университет (г. Челябинск, Российская Федерация), zagrebina_sophiya@mail.ru. 